\title{
Balance-of-Payments Deficits: Measurement and Interpretation
}

\author{
by JOHN PIPPENGER
}

\begin{abstract}
John Pippenger is Associate Professor of Economics with the University of California at Santa Barbara. He received a PhD degree in economics from the University of California at Los Angeles. His major field of interest is international finance, a topic on which he has published several articles. The author is a visiting scholar at the Federal Reserve Bank of St. Louis while on leave from the University of California for the 1973-74 academic year.
\end{abstract}

Us

NTIL a few years ago only a few economists and public officials were concerned about our balance of payments. Today balance-of-payments figures are frequently reported and widely discussed. Unfortunately, for most people balance-of-payments terminology is a jungle and balance-of-payments statistics are a mystery.

The first part of this article provides an explanation of terms commonly used in discussions of the balance of payments (BOP). The second part examines three common methods of measuring balance-of-payments deficits and attempts to provide a foundation for a useful interpretation of these and other ways of measuring a deficit.

\section{TEMS AND CONCERTS}

Balance-of-payments terminology, which has evolved over many years, can be misleading. It is therefore useful to examine the terminology in order to understand more fully what we read and hear about our balance of payments.

In principle, the balance of payments is a record of the value of all transactions between domestic and foreign residents over a given period of time, usually one year. The balance of payments is based on the principle of double entry bookkeeping and the dollar value of every transaction is recorded as both a credit and a debit. In practice, however, many transactions between domestic and foreign residents are only partly recorded, are estimated on the basis of surveys, or are missed entirely. We will discuss later some of the problems caused by incomplete recording of transactions. Here we examine the basic principles of BOP accounting.

\section{Credis and Dobis}

Partial balance-of-payments statistics probably were first collected during mercantilist days. Under crude mercantilist doctrine the immediate goal of international trade was the accumulation of treasure, that is gold and silver. Since exports normally were paid for with gold or silver (or currencies convertible into gold or silver), exports were viewed as desirable and the export of anything was entered in the balance of pay. ments as a plus or credit item. Imports normally required payment in gold or silver. They were viewed as something bad and were entered in the balance of payments as a negative or debit item. Following this approach, when we export more goods than we import we call that a favorable balance of trade. Today, as in 1750 , the purchase or import of anything from a foreign resident is recorded as a debit or minus entry in the balance of payments while the sale or export of anything to a foreign resident is recorded as a plus or credit item. 
Since exports are recorded as credits and balanceof-payments statistics follow the principle of double entry bookkeeping, the payment we receive for our exports must be recorded as a debit. Since imports are debits, it follows that the payment we make on imports must be recorded as a credit. That is, what we give up in every transaction is recorded as a credit and what we get is recorded as a debit.

For example, brush aside the "veil of money" and think of the United States as importing Japanese radios and paying for those radios by exporting wheat. The value of the radios we receive from Japan is entered on the debit side of the U.S. balance of payments and the value of the wheat we give up in order to obtain the radios is entered on the credit side of the balance of payments.

If debits and credits are shown independently in the form of a T-account as in Table $I$, then debits are usually shown on the right-hand side and credits on the left-hand side. This, of course, is the reverse of standard accounting procedure. In addition, although crediting sales and debiting purchases is consistent with standard accounting procedures, this approach conflicts with basic economic theory. From the point of view of economics, what we get (import) is the good or plus side of a transaction, while what we give up (export) is the bad or minus side.

\section{Subdvivisions}

Debits and credits in the balance of payments are collected into groups on the basis of what is exported or imported. The precise partitioning of these groups varies between countries and over time. As an introduction, we divide the balance of payments into four traditional subdivisions: (1) current account, (2) unilateral account, (3) capital account, and (4) gold account. ${ }^{1}$

The current account shows the value of all the goods and services we import or export as well as the payment and receipt of dividends and interest.

A unilateral accotint is necessary because a gift is a one-sided transaction. If we export something as a gift, there is no payment. In order to meet the requirement of double entry bookkeeping, we create a unilateral account and enter in that account what would have been the payment for the gift. In addition to a purely accounting function, a unilateral or

1The Department of Commerce includes the millateral account as part of the cutrent account under remittances, pensions, and other transfers as well as U.S. government grants. See Table II. gift account also helps separate gifts from other transactions. It should be understood, however, that a unilateral account does not record what we give or receive as a gift, but what would have been the payment. Thus, a debit entry in a unilateral account indicates that we gave a gift, not that we received one.

The capital account records the import and export of assets such as bonds and common stocks. More precisely, if the import or export of anything represents a change in claims, then its value is entered in the capital account.

All official purchases or sales of gold are recorded in the gold account. The import and export of gold for commercial purposes, however, are entered in the current account.

\section{Capital Flows}

Shori Term and Long Term - The capital account traditionally is divided into two parts, short term and long term. Claims such as demand deposits, bonds, and certificates of deposit whose maturity at time of issue is one year or less are considered short term, and any change in those claims is entered in the short-term category. Claims in the form of direct investments, corporate stocks, and bonds of over oneyear maturity at time of issue, are considered long term. Any changes in these claims are entered in the long-term category.

Inflows and Outfows - In discussing accounts other than the capital account, the tradition is to concentrate on what is bought or sold. In discussing the capital account, however, the tradition is to concentrate not on the bond or other asset bought or sold, but on the payment.

The import of a bond or any other similar asset is a debit item in the capital account. Since its purchase results in U.S. residents paying out money or capital, the import of a bond, like any other debit entry in the capital account, is called a capital outflow. On the other hand, the export of a bond means U.S. residents receive money or capital; thus, the $e x$ port of a bond, like any other credit entry in the capital account, is called a capital inflow.

If an entry appears as part of the short-term capital account, then the transaction is referred to as a short-term capital flow. Similarly, if an entry appears as part of the long-term capital account, it is called a long-term capital flow. For example, the export of a three-month U.S. Treasury bill is called a short-term capital inflow and the import of common stock is referred to as a long-term capital outflow. 
The following rule determines whether a capital flow is a credit or debit. If an entry in the balance of payments is due to an increase in foreign claims on the United States or a decrease in U.S, claims on foreigners, then it is a credit. If an entry is due to an increase in U.S. claims on foreigners or a decrease in foreign claims on the United States, it is a debit.

This rule is difficult enough to follow when it is read, and even more difficult to remember. Fortunately, the rule follows directly from the basic principle that all imports are debits and all exports are credits. Consider the import of a bond. It must be a debit. If it is a foreign bond, the import of the bond represents an increase in U.S. claims on foreigners. If it is a domestic bond, the import of the bond represents a reduction in foreign claims on the United States. Therefore, an increase in U.S. claims on foreigners, or a decrease in foreign claims on the United States must be debit entries since they are the result of the import of a bond.

Consider the export of a bond. It must be a credit. If it is a foreign bond, the export of the bond represents a decrease in U.S. claims on foreigners. If it is a domestic bond, the export of the bond represents an increase in foreign claims on the United States. An increase in foreign claims on the United States, or a decrease in U.S. claims on foreigners, therefore, must be credit entries since they are the result of exporting bonds.

\section{Whstratovs}

Some illustrations can help us understand how transactions are recorded in the balance of payments. Each transaction considered here appears in Table I beside the number of the example. In example (1) a ten-year loan of $\$ 1$ million is made to Russia; that is, some U.S. resident, or the U.S. Government, buys a ten-year Russian bond for $\$ 1$ million. Normally this would be paid for with a check which, again for simplicity, we assume is deposited by the Russian Government in a New York bank. The import of the bond represents an increase in U.S. long-term claims on foreigners and appears as a $\$ 1$ million debit in the long-term capital account. This side of the transaction is called a long-term capital outflow.

The other side of the transaction, the payment for the bond, takes the form of an increase in foreign short-term claims on the United States (the increase in foreign short-term claims on the United States is also referred to as an increase in U.S. short-term liabilities to foreigners). The payment side of this

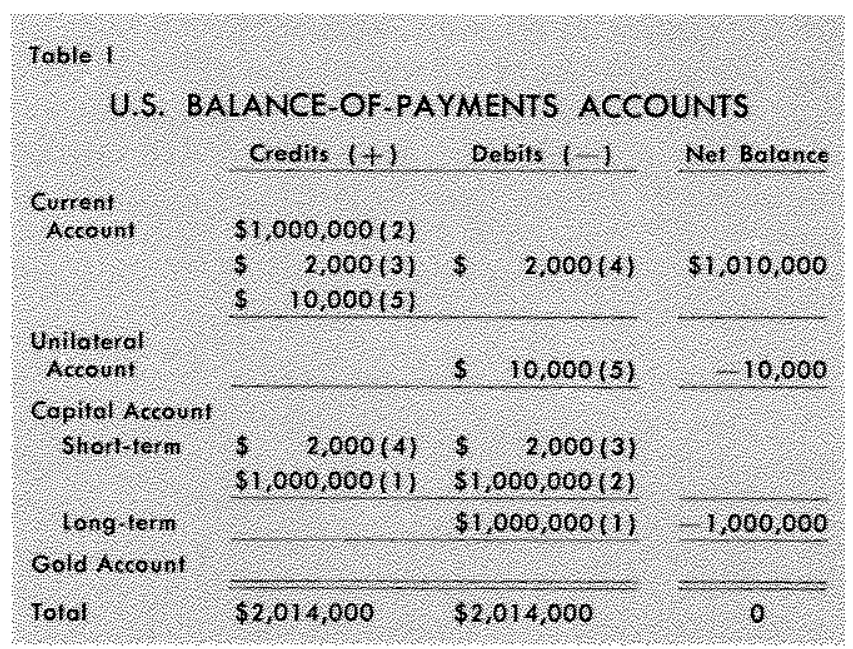

transaction appears as a $\$ 1$ million credit entry in the short-term capital account and is called a short. term capital inflow.

In example (2) consider a $\$ 1$ million sale of wheat to Russia by a U.S. corporation, where the Russian Government uses the money it borrowed in example (1). The export of wheat appears as a one million dollar entry on the credit side of the current account. The payment for the wheat reduces Russian demand deposits in U.S. banks (that is foreign short-term claims on the United States decline), and the payment side of the transaction appears as a debit entry of $\$ 1$ million in the short-term capital account. The payment side of the transaction is called a shortterm capital outflow.

It might be instructive before going on with other examples to consider the net effect on the balance of payments of examples (1) and (2). Since the $\$ 1$ million short-term capital inflow in example (1) is just offset by a $\$ 1$ million short-term capital outtlow in example (2), the net result of examples (1) and (2) is that the United States has a current account credit and long-term capital debit of $\$ 1$ million. That is, these two transactions taken together generate a $\$ 1$ million credit on current account that is financed or offset by a $\$ 1$ million long-term capital outflow.

In example (3) a U.S. resident receives $\$ 2,000$ in dividends from common stock he owns in a French corporation. For simplicity we assume he deposits the funds in a French bank. The dividends are recorded as a credit item in the current account. This makes sense since dividends essentially represent payment for the services of capital. The payment he receives for these services takes the form of an increase in short-term claims on foreigners and it is recorded as a debit item in the short-term capital account. 
In example (4) the U.S. resident uses the $\$ 2,000$ to finance a holiday in the south of Spain. His tourist expenditures represent purchases of goods and services from nonresidents and they are entered as a debit item in the current account. The reduction in his demand deposit at a French bank is a short-term capital inflow and it is recorded as a credit item under short-term capital.

It is useful to consider the combined effects of examples (3) and (4). The short-term capital flows cancel each other and there is no net effect on the short-term capital account. There is a debit entry under tourist expenditures and a credit entry under interest payments, but there is no net effect on the current account.

In example (5) the U.S. Government sends $\$ 10,000$ worth of grain to a drought-stricken foreign country as a gift. The export of grain appears as a $\$ 10,000$ entry on the credit side of the current account, but in this ease there is no payment. In order to maintain the system of double entry bookkeeping, an entry of $\$ 10,000$ is recorded on the debit side of the unilateral account. The wheat, of course, is the gift, but since there is no payment for a gift, the unilateral account is needed to maintain the rule that every transaction must appear on both the debit and credit sides of the balance of payments.

In published BOP statistics, credits and debits for each category usually are not shown separately. The normal practice is to subtract debits from credits and show only the net balance for each category. The far right column of Table I shows the net balance for the five examples.

\section{Reported Dalu}

The discussion up to this point has been concerned with the balance of payments in principle rather than in practice. BOP statistics reported by the Department of Commerce differ in several important ways from the form discussed above. ${ }^{2}$

As mentioned above, all transactions are not reported and in some cases only one side of a transaction is reported. If neither side of a transaction is reported, the published BOP figures are simply incomplete. If only one side of a transaction is reported, then the total of reported debits does not equal the total of reported credits and the principle of double entry bookkeeping is violated.

2For a more detalled explanation of the statistics reported by the Department of Commerce, see David $T$. Devlin, "The U.S. Balance of Payments: Revised Presentation," Survey of Current Business (June 1971), pp. 24-57, 64 .
In order to maintain the principle of double entry bookkeeping, another account is created called "errors and omissions." If, after all the numbers have been collected, the sum of debit items does not equal the sum of credit items (as is always the case), then the difference between debits and credits is entered on the appropriate side of the account for errors and omissions, making total debits and credits including errors and omissions equal.

A second difference between the balance of payments discussed earlier and the data reported by the Department of Commeree is that the reported figures distinguish between liquid and nonliquid as well as between short-term and long-term capital flows. Except for certain long-term U.S. Treasury bonds held by foreign official reserve agencies, long-term claims are considered nonliquid. In addition, short-term claims on foreignets of U.S. banks and nonbanking concerns that are not readily marketable or transferable, such as trade credits and cash items in process of collection, are considered nonliquid. Other short-term claims on foreigners, such as demand deposits, time deposits, and negotiable securities, are considered liquid. All short-term liabilities to foreign residents of U.S. nonbanking concerns are considered nonliquid and, in practice, all short-term liabilities to foreign residents reported by U.S. banks are considered liquid.

In addition to the liquid versus nonliquid distinction, published BOP statistics also identify capital flows according to whether the holder of the claim is a private organization or individual, an official agency, or an official reserve agency. Treasuries, finance ministries of national governments, and recognized central banks are viewed as official reserve agencies. Official agencies include official reserve agencies plus diplomatic and consular establishments as well as other agencies of national governments.

\section{TNTERPRETATION}

As emphasized above, BOP accounting is based on the principle of double entry bookkeeping. Total debits must equal total credits, and it is impossible for the entire balance of payments to show either a deficit or a surplus. The only way we can observe a difference between credits and debits is to select certain items out of the balance of payments and compare credits and debits for the given subset of items. Whatever subset we choose, the deficit (surplus) on that set of items must be matched by an identical balance with opposite sign on the remaining items. According to current usage, a line is drawn through the balance of payments and the items selected are said to be 
"above the line" and the remaining items are said to be "below the line."

Over the years the line has been drawn at many different places and several different measurements currently are reported by the Department of Commerce. At least three of these are commonly cited and discussed. They are (1) the balance on current account plus long-term capital, (2) the net liquidity balance, and (3) the official reserve transactions balance. $^{3}$

Enumerating in great detail the items that go above and below the line for each of these measures is tedious and not very useful for our purposes. Instead this section gives a general description of the items above and below the line for each of the three ways of measuring a deficit and suggests a way to interpret these deficits. ${ }^{4}$

By placing certain items above and below the line we define a deficit. Since all such definitions are, in a trivial sense, correct, we must select between alternative measurements on the basis of their usefulness. No way of measuring a deficit is useful in isolation. In order to be meaningful a deficit must be related through some theory to a relevant problem.

In interpreting a given deficit, it is helpful to ask two questions. First, what problem is this measurement supposed to help me understand? Second, what explicit (or implicit) theory underlies this particular definition of a deficit? Although we consider only one relevant problem and appropriate theory for each deficit, there are other reasonable interpretations.

\section{Cunent Accontrind Long-Tem Capint}

Measurement - As suggested by the heading, under this approach long-term capital flows (other than cer tain official long-term flows) and the balance on current account go above the line (see Table II). The

3 For a discussion of these and other ways of measuring a deficit, see the following: The Balance of Payments Statistics of the United States: A Review and Appraisal Report of the Review Committee for Balance of Payments Statistics to the Bureau of the Budget (April 1965); Hal B. Lary, Problems of the United States as World Trader and Banker

(New York: NBER, 1963); Richard N. Cooper, "The Balance of Payments in Review," Journal of Political Economy (August 1966), pp. 379-95; Walter R. Gardner, "An Exchange-Market Analysis of the U.S. Balance of Payments," IMF Stafl Papers (May 1961), pp. 195-211: Anne O. Krueger, "Balance-of-Payments Theory," Joumal of Economic Literature (March 1969), pp. 1-26; Walther Lederer, The Balance of Foreign Transactions: Problems of Definition and Measurement, Special Papers in International Economics, Princeton University, September 1963; and Devlin, U.S. Balance of Payments:- Revised.

4 For a detailed description, see Devlin, U.S. Balance of Payments: Revised.

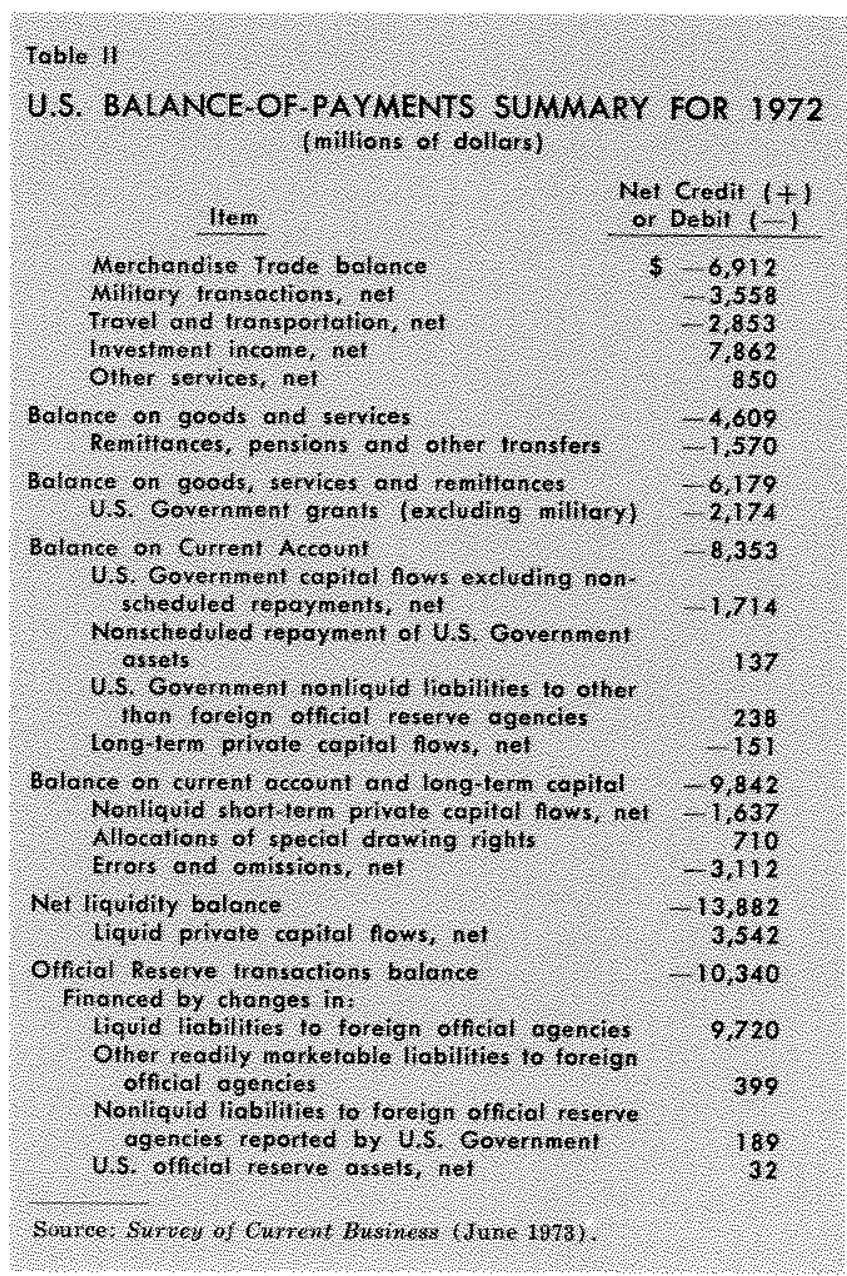

remaining items, errors and omissions, short-term capital flows, and changes in official claims, all go below the line as financing items.

problem and Theory - The balance on current account and long-term capital is intended to serve as an indicator of basic or long-term trends in U.S. balance of payments. For this reason it is sometimes referred to as the basic balance. The problem relevant to this approach is whether or not the balance of payments is in equilibrium in the sense that a given situation can persist through time.

The following ideas appear to underlie this approach. It is generally considered both proper and possible to finance a current account deficit by incurring long-term debt or to make long-term foreign investment by running a current account surplus. But it is generally considered neither possible nor proper to finance a persistent long-term capital outflow and/or a current account deficit by incurring shortterm debt or reducing international reserves. This view apparently assumes that there is a limited pool of internationally mobile short-term capital that can- 
not be relied upon because it moves from country to country in response to expectations as well as to modest and temporary advantages in net yields.

Given this view of the world, a deficit or surplus on current account plus long-term capital financed by a short-term capital inflow is only temporary. The short-term capital inflow financing the net debit balance above the line will disappear and perhaps turn into a capital outflow in response to changing international financial conditions, especially changes in relative short-term yields between countries. A net balance on current account plus long-term capital therefore represents a disequilibrium in the sense that this situation cannot be expected to continue.

The quarterly balance on current account and longterm capital from 1960 through the second quarter of 1973 is shown in the accompanying chart. Although deficits were posted generally throughout the $1960 \mathrm{~s}$, they were relatively small and did not show any clear signs of increasing until late in the decade. By 1969 the deficits became substantial and then in the second and third quarters of 1971 they rose sharply. Toward the end of 1972 the deficit on current account and long-term capital fell sharply and remained relatively small through early 1973.

Without some additional theory, a deficit on current account and long-term capital, such as the $\$ 4$ billion deficit in the third quarter of 1971 , does not convey much information. ${ }^{5}$ Knowing that a given situation is likely to change is not very revealing unless we also have at least some indication of how it is going to change and what that change means for the problem with which we are concerned.

\section{Net Licuidity Base}

Measurement - The Department of Commerce now reports the deficit on a "net liquidity" basis rather than a "gross liquidity" basis. As shown in Table II, in going from the balance on current account plus long-term capital to the net liquidity balance, errors and omissions, allocations of Special Drawing Rights, and nonliquid short-term capital flows are moved above the line. This leaves primarily liquid capital flows, changes in nonliquid liabilities to official reserve agencies, and changes in U.S. official reserve assets below the line to finance the deficit or surplus on the items above the line.

Problem and Theory - The relevant problem for this approach is again whether a given situation can

All deficits cited in this paper refer to non-seasonally adjusted data.

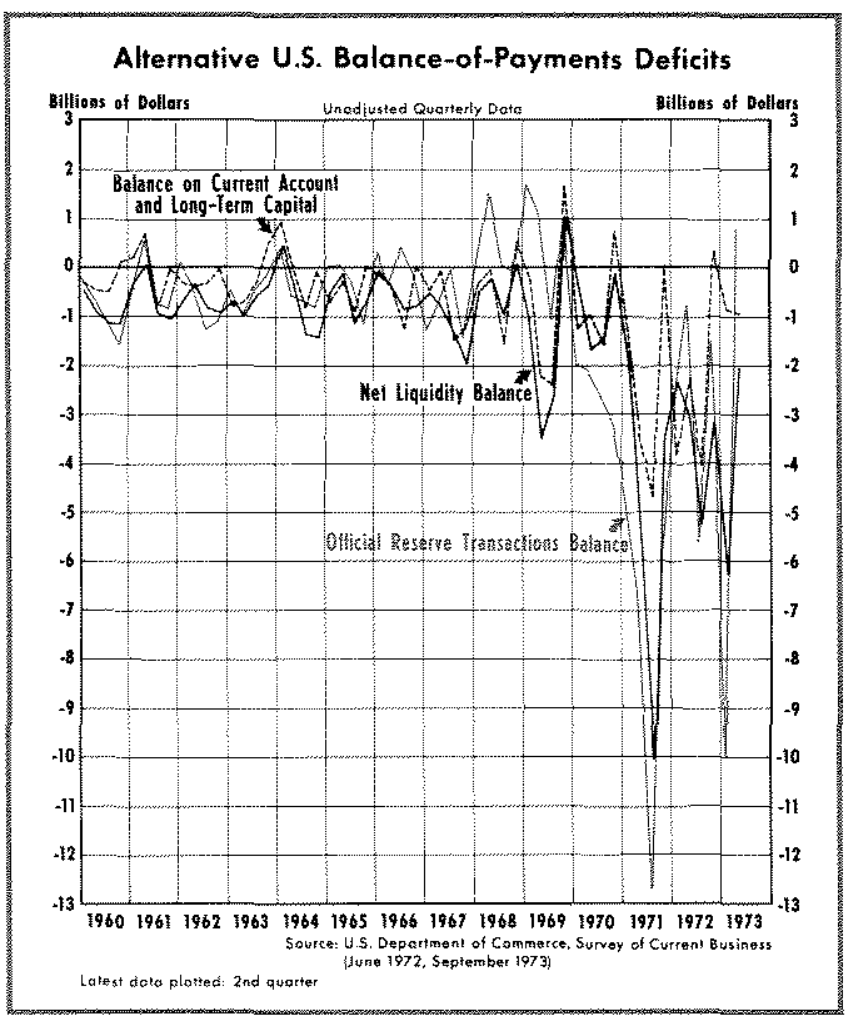

persist. The theory underlying the approach appears to be that entries below the line represent largely transitory items that cannot be relied on to finance a persistent deficit or surplus on the entries above the line.

If trade credit and other nonliquid short-term clains grow essentially automatically with the volume of trade, and errors and omissions are not dominated by unreported short-term capital flows, then the net liquidity measurement would appear to be a more useful indicator of basic or long-term trends in U.S. balance of payments. If, on the other hand, nonliquid short-term capital behaves essentially like liquid shortterm capital and errors and omissions are dominated by unreported liquid short-term capital, then the balance on current account and long-term capital would be a more appropriate measure of basic balance.

The chart presented above shows the quarterly balance on a net liquidity basis from 1960 through the second quarter of 1973. The pattern suggests that, at least in times of crises, errors and omissions as well as trade credit behave very much like liquid short-term capital flows. During the third quarter of 1971 a deficit of about $\$ 4.6$ billion on current account and long-term capital was expanded to about a $\$ 10$ billion deficit on a net liquidity basis by the inclusion of about a $\$ 5$ billion deficit in errors and omissions. During the 
first quarter of 1973 a relatively modest deficit of less than $\$ 1$ billion on current account and long-term capital became a deficit of over $\$ 6$ billion on a net liquidity basis. This was primarily the result of an increase in nonliquid claims on foreigners reported by U.S. banks of over $\$ 1.5$ billion dollars and a debit entry of almost $\$ 4$ billion in errors and omissions. Given the recent behavior of nonliquid short-term capital flows as well as errors and omissions, it does not seem appropriate to place these items above the line.

If we view both the balance on current account plus long-term capital and the net liquidity balance as measures of fundamental or long-term trends in the balance of payments, then the choice between these two approaches depends on what theory we accept. If we believe errors and omissions and nonliquid short-term capital respond to exchange rate speculation and interest rate differentials in essentially the same way as liquid short-term capital, then we should place these items below the line and use the balance on current account plus long-term capital. If, on the other hand, we believe nonliquid capital flows and errors and omissions reflect essentially the same forces that determine the volume of trade and long-term capital flows, then we should place nonliquid capital flows and errors and omissions above the line and use the net liquidity balance.

If we believe the relevant problem is different for the balance on current account plus long-term capital and the net liquidity balance, then the choice between these two approaches should depend primarily on our belief about which problem is more important. Explicit separation of the appropriate problem from the appropriate theory would go a long way toward resolving the continuing debate over how to measure a balance-of-payments deficit.

\section{Offorl Pescrue Transactoms}

Mensurmer. - In going from the net liquidity basis to the balance on official reserve transactions, liquid private capital flows are moved above the line. This leaves changes in official U.S. reserve assets (holdings by the Federal Reserve and U.S. Treasury of gold, SDRs, gold tranche position at the International Monetary Fund, and foreign currencies), changes in U.S. liquid liabilities to foreign official agencies, and changes in nonliquid liabilities to official reserve agencies as the financing items below the line (see Table II).

Problem and Theors - Under a fixed exchange rate, the problem relevant to the official reserve transac-

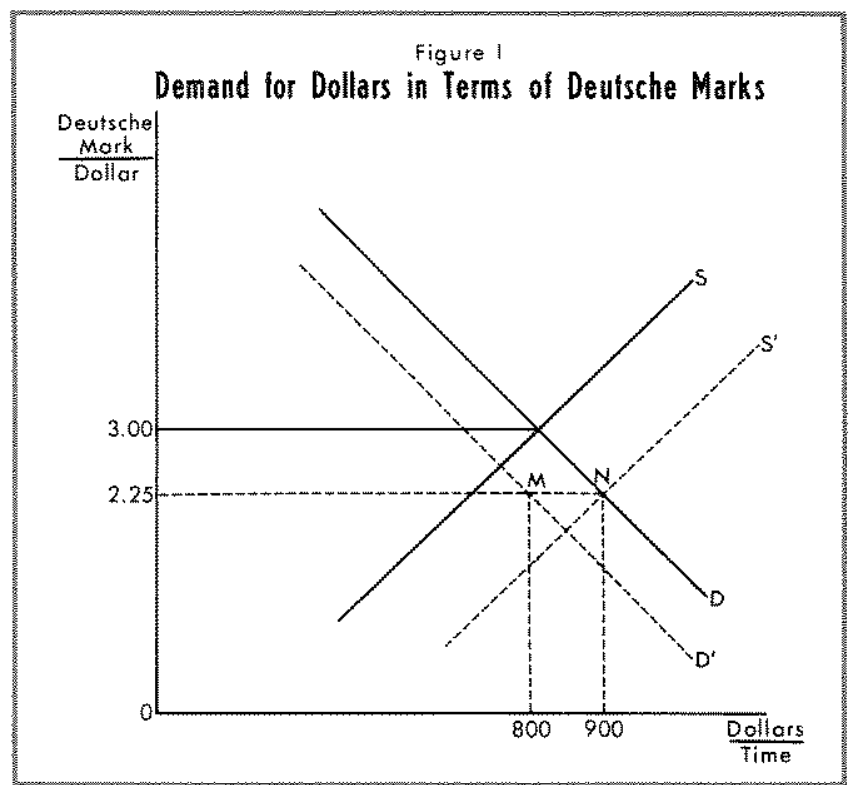

tions balance is the amount of pressure on the pegged rate in the foreign exchange market. Under a "dirty" float (flexible rates with official intervention) the relevant problem is the direction and magnitude of official intervention. The theory underlying this approach is simple supply and demand.

Suppose there is a dirty float between the dollar and most of our major trading partners. Initially an exchange rate of 3 Deutsche marks per dollar just equates demand and supply for dollars in terms of D-marks without official intervention, as shown in Figure $I$ by the lines $\mathrm{D}$ and $\mathrm{S}$. There is then additional downward presstre on the dollar as private demand and supply shift to $D^{\prime}$ and $S^{\prime}$, respectively. If the Bundesbank (German central bank) intervenes and partially offsets this downward pressure by buying MN dollars, as shown in Figure 1, then the Bundesbank acquires claims worth $\$ 100,000$ which go below the line. This $\$ 100,000$ appears as a credit below the line reflecting a deficit on the items above the line. This intervention therefore generates a deficit of $\$ 100,000$ on the official reserve transactions basis. If private demand and supply then shift so as to raise the D-mark price of the dollar and the Bundesbank partially offsets that movement, the Bundesbank would sell dollars and this would contribute to a surplus on the official reserve transactions basis.

If, over a given period of time, the official reserve transactions basis shows a surplus, then this is an indication that over the period as a whole central banks have been selling dollars and, on balance, moderating a rise or contributing to a fall in the price of the dollar in terms of foreign currencies. A deficit on the official reserve transactions basis indicates that cen- 
tral banks have been buying dollars in foreign exchange markets and thereby moderating the fall or adding to the rise in the price of dollars in terms of foreign currencies.

Although the balance on official reserve transactions is positive for some quarters during the $1960 \mathrm{~s}$, in most quarters there was a deficit (see chart). Throughout the 1960s the deficits were not large by recent standards and, perhaps even more important, deficits did not tend to grow.

Looking back we can now see that the deficit on an official reserve transactions basis began to grow rapidly in 1970. By the first quarter of 1971 the deficit was larger than it had ever been in the 1960 s. We can interpret the growth in this deficit from slightly less than $\$ 2$ billion in the first quarter of 1970 to over $\$ 6$ billion by the second quarter of 1971 as an indica. tion of large and growing market pressure against the fixed price of the dollar.

With the floating of the German mark and Netherlands guilder in May 1971, the structure of fixed exchange rates began to crumble. Widespread anticipation of a general breakdown apparently generated massive pressure against the dollar in foreign exchange markets. This pressure is reflected in a third quarter deficit for 1971 of over $\$ 12$ billion.

With the realignment of exchange rates worked out at the Smithsonian Meetings in December 1971, pressure against the dollar slowly declined through early 1972, but then began to increase. In early 1973 there was strong pressure against the new structure of exchange rates. The magnitude of the official intervention required to protect the rate structure adopted at the Smithsonian Meetings is reflected in a deficit for the first quarter of 1973 of over $\$ 9$ billion.

By the end of March 1973, most industrialized countries had stopped pegging the dollar and had adopted a dirty float. The relatively small surplus in the second quarter of 1973 for the balance on official reserve transactions suggests that, on balance, central banks sold dollars and tended to accentuate the depreciation of the dollar. If speculators had followed the same policy, their actions probably would have been described as destabilizing.

Although there are problems associated with every definition of a deficit, under most circumstances the balance on official reserve transactions does give at least a general idea of the direction and magnitude of official intervention in foreign exchange markets. Whether or not the balance on official reserve trans- actions is the appropriate deficit to consider depends primarily on whether or not you consider conditions in the foreign exchange market as the appropriate problem.

\section{Caveras}

Even if the problem and supporting theory for a given definition of a deficit are reasonably well spelled out, using that definition can be misleading. ${ }^{\text {" There }}$ are at least four reasons tor this.

First, classification of items is highly arbitrary and accounts often do not accurately refiect the corresponding theoretical concept. For example, long-term capital flows include the import and export of longterm bonds with only three months left until maturity. From a conceptual point of view, a three-month Treasury bill and a 20 -year bond with three months left until maturity are essentially equivalent assets.

Second, the collection of BOP statistics is a very difficult and complex task. Many transactions are only partially reported, estimated on the basis of surveys, or missed entirely. As a result, balance-ofpayments statistics should be taken with a grain of salt.

Third, in measuring a deficit there is a tendency to think that the balance should be zero. In most cases, however, there is nothing inherently good about a zero balance, For example, a deficit on the official transactions balance presumably would be preferable to a zero balance enforced by strong trade and capital controls.

Fourth, in addition to all the unavoidable problems, governments often engage in practices (both deliberately and accidentally) that distort the statistics. For example, suppose a foreign central bank bought $\$ 1$ billion in the foreign exchange market, but deposited the dollars in a Eurodollar account in a London bank rather than depositing them in the United States or buying U.S. Treasury bills. The effect of this intervention in the foreigi exchange market would not appear in the balance on official reserve transactions because the $\$ 1$ billion would not be reported as an increase in U.S. liabilities to foreign official reserve agencies. Instead, it would be reported as a $\$ 1$ billion increase in U.S. liabilities to foreign commercial banks and the $\$ 1$ billion entry would go above the line when measuring the deficit as the balance on official reserve transactions.

\footnotetext{
${ }^{5}$ For a more detaled discussion of some of these problems, see Devlin, U.S. Balance of Poyments: Revised, and Cooper, Balance of Payments in Review.
} 


\section{SUMMARY}

The first part of this article discusses balance-ofpayments terminology. At least three basic points are made in that discussion. First, the balance of payments is a product of double entry bookkeeping and total debits must equal total credits. Second, what we receive in every transaction (import) is recorded as a debit and what we give up in every transaction (export) is recorded as a credit. Third, imports and exports of assets or claims, such as stocks and bonds, are referred to as capital flows; the import of stocks and bonds is called a capital outflow and the export of these assets is called a capital inflow.

The second part discusses how we can interpret balance-of-payments statistics. Since the balance of payments must balance, a particular way of measuring a deficit or surplus is a definition. Like all definitions, a definition of what is a deficit must be judged on its usefulness. In order to be useful, a particular way of measuring a deficit must be linked through some kind of theory to a relevant problem.

Without reference to a problem and supporting theory, a simple statement that the U.S. balance of payments is in deficit is meaningless. Even with a complete specification, a balance-of-payments deficit should not necessarily generate a call for action to eliminate this deficit. Suggestions or demands for action can be based only on a specification of the deficit and an argument as to why this particular deficit is detrimental.

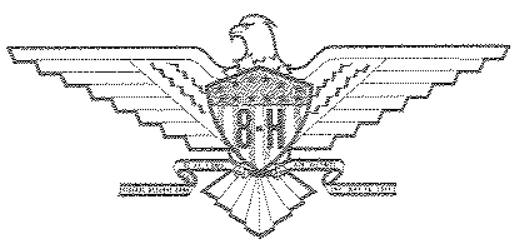

